tion to the recently published or soon to be published works of Lucy Dawidowicz, Raphael Mahler, Lionel Kochan, Ezra Mendelsohn, Zvi Gitelman, and Henry Tobias, are welcome confirmation of this growing interest.

Ezra Mendelsohn

The Hebrew University of Jerusalem

\title{
REVOLUTION UND RÄTEREPUBLIK IN BREMEN. Edited by Peter Kuckuk. Frankfurt am Main: Suhrkamp Verlag, 1969. 181 pp. DM 3, paper.
}

This paperback is primarily a collection of documents on the revolution in Bremen between November 6, 1918, and February 4, 1919. The documents are divided into three major groups: proclamations, resolutions, and public announcements; protocols of the Workers' and Soldiers' Council meetings; and eyewitness and memoir accounts. The compact introduction and conclusion outline the three major phases of the Bremen revolution: (1) the period of dual authority between the Workers' and Soldiers' Councils and the Senate from November 6 to 14, (2) political control by the Workers' and Soldiers' Councils, following the dismissal of the Senate, from November 15,1918, to January 10,1919, and (3) the rule of the Soviet government (Räterepublik) from January 10 to February 2, 1919. A short bibliography is appended, but there is no index.

Kuckuk is critical of the USPD/KPD coalition for failing to implement sweeping social and economic reforms. He also castigates the KPD for its "inability to understand the nature of political power." But, on the whole, his sympathies clearly lie with the two left-wing socialist parties. He accepts their analogy of the German November revolution as a parallel to the Russian February revolt, and the abortive Spartacist uprising in January 1919 as a parallel to the Russian October Revolution. The SPD earns Kuckuk's contempt for siding with the ancien régime against the forces of revolution. In April 1919, after the conquest of the city by free corps units acting under orders from Gustav Noske, the SPD formed a coalition government with bourgeois parties. This, the editor believes, firmly established continuity between the Wilhelmian Empire and the Weimar Republic, thereby downgrading the revolution to a mere "episode."

The major fault of the book is that Kuckuk overrates the importance of Bremen. He describes the city as "the strongest Communist bastion" in Germany and claims that Noske was bent on making it, rather than Munich, an "example" of counterrevolutionary strength. But Bremen, as the editor admits, proved to be the exception by January 1919. While in the Reich the SPD ruled and the USPD and KPD were in opposition, in Bremen the roles were reversed. Above all, there is little correlation between events in Bremen and in Berlin. The decision of the "Bremen Left Radicals," after November 23 the "German International Communists" (IKD), to join with the Spartacists on December 31 to form the KPD is relegated to a footnote; the First German Congress of Workers' and Soldiers' Councils, held in Berlin between December 16 and 21, is not even mentioned; and the Spartacist uprising in January 1919 is also not tied in with events in Bremen. In short, the student of the German revolution is left with more questions than answers.

Holger H. Herwig Vanderbilt University 